\title{
GAMBARAN EMPATI DASAR MAHASISWA BIMBINGAN DAN KONSELING ETNIS BATAK DI DKI JAKARTA
}

\author{
Abdul Hayi ${ }^{1}$ \\ Dra. Endang Setyowati ${ }^{2}$ \\ Drs. Djunaedi, M.Pd ${ }^{3}$
}

\begin{abstract}
Abstrak
Tujuan penilitian ini adalah untuk mengetahui gambaran empati dasar mahasiswa Bimbingan dan Konseling Etnis Batak se-DKI Jakarta.Teknik yang digunakan dalam penelitian ini adalah teknik sensus dengan jumlah responden 18 orang. Ujicoba dilakukan dengan menggunakan instrumen bakuBasic Empathy Scale (BES) dan dianalisa dengan menggunakan Ms.Excel. pengumpulan data menggunakan instrumen BES yang berisi 20 item pernyataan yang bertingkat. Tingkatan tersebut adalah sangat setuju (poin 5), setuju (poin 4), ragu-ragu (poin 3), tidak setuju (poin 4), dan sangat tidak setuju (poin 1). Analisis uji validitas instrumen menggunakan korelasi pearson product moment. Hasil uji validitas butir $r$ tabel 0,312. Uji reliabilitas dengan rumus alpha cronbach didapatkan hasil 0,833 yang berarti bahwa instrumen memiliki reliabilitas sangat tinggi dan layak digunakan sebagai instrumen penelitian.Hasil keseluruhan menunjukkan $78 \%$ mahasiswa Bimbingan dan Konseling Etnis Batak di DKI Jakarta berada pada kategori sedang. 11 \% berada pada kategori tinggi dan rendah. Pada aspek kognitif empati dasar mahasiswa Bimbingan dan Konseling Etnis Batak 72 \% berada pada kategori sedang, 17\% pada kategori tinggi, dan $11 \%$ menunjukkan posisi rendah. Pada aspek afektif empati dasar mahasiswa Bimbingan dan Konseling Etnis Batak 66 \% berada pada kategori sedang, serta 17 $\%$ pada masing-masing kategori tinggi dan rendah.
\end{abstract}

Kata kunci : Empati Dasar, Mahasiswa BK, Etnis Batak

\section{Pendahuluan}

Daerah Khusus Ibukota Jakarta (DKI Jakarta) adalah salah satu provinsi yang mempunyai kekhususan dalam penyelenggaraan pemerintahan daerah karena kedudukannya sebagai Ibukota Negara Kesatuan Republik Indonesia. Berbagai aspek kehidupan yang berada didalamnya seperti bidang sosial, politik, ekonomi, kebudayaan, hukum, dan pendidikan memiliki peran yang sama pentingnya. Berapa jumlah populasi penduduk Jakarta? Jumlah populasi penduduk Provinsi DKI Jakarta sebanyak \pm 9,6 juta jiwa (BPS, 2010). Terdiri atas orang Jawa sebanyak $36,8 \%$, Betawi $28,9 \%$, Sunda $14,3 \%$, Tionghoa 5,6\%, Minangkabau 2,9\%, Batak 2,6\% (Sensus Penduduk, 2010). Pendidikan merupakan salah satu indikator keberhasilan bangsa sesuai dengan fungsi pendidikan menurut Undang-Undang Sistem Pendidikan Nasional No. 20 Tahun 2003 pasal 3, yaitu:

\footnotetext{
Mahasiswa Jurusan Bimbingan dan Konseling FIP UNJ, abdulhayi10@gmail.com

2 Dosen Bimbingan dan Konseling FIP UNJ, esetiyowati63@yahoo.com

3 Dosen Bimbingan dan Konseling FIP UNJ, djunaediunj@yahoo.co.id
} 
"mengembangkan kemampuan dan membentuk watak serta peradaban bangsa yang bermartabat dalam rangka mencerdaskan kehidupan bangsa, bertujuan untuk berkembangnya potensi peserta didik agar menjadi manusia yang beriman dan bertakwa kepada Tuhan Yang Maha Esa, berakhlak mulia, sehat,berilmu, cakap, kreatif, mandiri, dan menjadi warga negara yang demokratis serta bertanggung jawab."

Lebih lanjut dalam UU No. 20 tentang SISDIKNAS Tahun 2003 menerangkan dalam Bab 1 Pasal 1 ayat 6 bahwa "Pendidik adalah tenaga kependidikan yang berkualifikasi sebagai guru, dosen, konselor, pamong belajar, widyaiswara, tutor, instruktur, fasilitator dan sebutan lain yang sesuai dengan kekhususannya, serta berpartisipasi dalam menyelenggarakan pendidikan.

Merujuk pada UU No. 20/2003 tentang Sistem Pendidikan Nasional, sebutan untuk guru pembimbing dimantapkan menjadi "Konselor". Keberadaan konselor dalam sistem pendidikan nasional dinyatakan sebagai salah satu kualifikasi pendidik, sejajar dengan kualifikasi guru, dosen, pamong belajar, tutor, widyaiswara, fasilitator dan instruktur (pasal 1 ayat 6). Pengakuan secara eksplisit dan kesetaraan posisi antara tenaga pendidik satu dengan yang lainnya tidak mengesampingkan arti bahwa setiap tenaga pendidik, termasuk konselor, memiliki konteks tugas, ekspektasi kinerja, dan setting layanan spesifik yang mengandung kekhasan dan kekhususan satu dengan yang lainnya.

Peran bimbingan dan konseling di sekolah sangat penting dan diharapkan mampu menangani ranah pendidikan formal yang saat ini masih kurang tersentuh. Pentingnya bimbingan dan konseling di sekolah menjadi sebuah tantangan bagi para konselor yang berada di sekolah maupun para calon konselor yang masih menempuh pendidikan ditingkat sarjana.

Masalah yang saat ini menjadi perhatian adalah bahwa profesi konselor tidak akan lepas dari pengaruh budaya pribadi dan konseli, hal ini dilandasi oleh konsep yang diajukan Segall (1990) bahwa adanya tingkah laku manusia yang dipandang dalam konteks sosial budaya dimana tingkah laku/perilaku terjadi. Deskripsi ini menggambarkan bahwa frame- work terhadap individu tidak dapat dipisahkan oleh pola kebiasaan asal individu, sehingga esensi latar belakang budaya konseli menjadi salah satu bagian penting yang tak terpisah untuk memahami individu. Bimbingan dan konseling dalam perspektif multikutural "menuntut" adanya kesiapan konselor menghadapi peserta didik dalam proses pelayanan bimbingan baik klasikal maupun kelompok dengan tidak menggunakan perspektif budaya pribadi sebagai acuan nilai yang akan digunakan oleh konseli. Konseling dalam perspektif multikultural diarahkan pada upaya konselor untuk memahami latar belakang budaya konseli sehingga konselor tidak serta merta menggunakan perspektif budayanya sendiri untuk dipakai sebagai sistem nilai yang harus dipahami oleh konseli.

Konselor dituntut untuk menjadi profesional dan memiliki karakteristik kepribadian yang ideal. Salah satu karakteristik untuk menjadi konselor profesional dipengaruhi dengan adanya sejumlah kualitas kepribadian. Konseling yang efektif berpengaruh pada hubungan dalam proses konseling dan kemampuan memahami orang lain salah satunya adalah empati. Hubungan antarpribadi yang menekankan empati atau pemahaman terhadap pikiran dan pe-rasaan yang terungkap oleh konseli, serta penerimaan terhadap situasi konseli, ternyata sangat esensial dan dapat ditemukan pada berbagai tipe kepribadian konselor yang efektif. (Belkin, 1981; Shertzer dan Stone 1980 dalam Winkel 1997).

Empati merupakan salah satu dari beberapa kualitas kepribadian konselor yang harus dimanifestasikan dalam relasi konseling (Patterson, 1996). Bahkan empati juga merupakan komponen utama yang menentukan efektivitas layanan konseling (McLeod, 2001).

Dalam realitasnya, perilaku dan pola kehidupan etnik Batak tampak sering dikesankan atas dasar prasangka subjektif oleh orang selain etnis Batak. Selain itu, etnis di luar Batak cenderung menganggap bahwa orang Batak itu adalah orang yang memiliki sosok yang angker, tidak kenal sopan santun, kasar, dan beringas. Sehingga membuat keberadaan mereka seolah-olah makin menyusut karena ternyata mereka mulai enggan bergaul lebih dekat dengan mahasiswa etnis Jawa dikarenakan anggapan yang sudah terlanjur melekat pada mereka sebagai orang 
Batak.

Berdasarkan permasalahan diatas, maka peneliti ingin mengetahui sejauh mana gambaran empati dasar mahasiswa BK Etnis Batak yang menempuh perkuliahan di DKI Jakarta. Hal ini untuk membantu para stakeholder di jurusan Bimbingan dan Konseling membantu mempersiapkan para calon konselor tersebut di lingkungan sekolah.

\section{Kajian Teori}

Egan (2008), mendeskripsikan empati sebagai keterampilan komunikasi interpersonal. Konselor berusaha untuk memahami konseli dan mengkomunikasikan pemahamannya dengan tujuan membantu konseli agar lebih memahami dirinya sendiri. Dikemukakan lebih lanjut bahwa empati merupakan orientasi nilai. Konselor berkomitmen untuk bekerja berdasarkan pemahamannya terhadap orientasi nilai dalam tiga cara yang berbeda. Pertama, konselor menunjukkan komitmen untuk berusaha memahami setiap konseli dari perspektif, dan emosi konseli tersebut melalui komunikasi secara konsisten dan tepat. Kedua, konselor memiliki komitmen untuk memahami setiap konseli dengan berfokus pada konteks kehidupan konseli. Ketiga, konselor memiliki komitmen untuk memahami setiap dissonansi antara realitas dan perspektif konseli.

Pengertian lain tentang empati disampaikan oleh Eisenberg (2002). Eisenberg mengatakan bahwa empati adalah sebuah respon afektif yang berasal dari penangkapan atau pemahaman keadaan emosi atau kondisi lain, dan yang mirip dengan perasaan orang lain. Sebuah respon afektif, yaitu sebagai orang lain dari situasi diri sendiri. Empati juga sebagai kemampuan untuk meletakkan diri sendiri dalam posisi orang lain dan mampu menghayati pengalaman orang lain tersebut. Sedangkan penangkapan atau pemahaman keadaan emosi, yaitu dimana empati terjadi ketika seseorang dapat merasakan apa yang dirasakan orang lain namun tetap tidak kehilangan realitas dirinya. Hal ini berarti emosi yang tergugah untuk ikut merasakan apa yang orang lain rasakan tidak lantas membuat seseorang menjadi kehilangan identitas dan sikap dirinya.

Lebih lanjut menurut Eisenberg (2002), bahwa dalam proses individu berempati melibatkan aspek afektif dan kognitif. a. Aspek afektif: aspek afektif merupakan kecenderungan seseorang untuk mengalami perasaan emosional orang lain yaitu ikut merasakan ketika orang lain merasa sedih, menangis, terluka, menderita bahkan disakiti

b. Aspek kognitif: aspek kognitif dalam empati difokuskan pada proses intelektual untuk memahami perspektif/sudut pandang orang lain dengan tepat dan menerima pandangan mereka, misalnya membyangkan perasaan orang lain ketika marah, kecewa, senang, memahami keadaan orang lain dari ; cara berbicara, dari raut wajah, cara pandang dalam berpendapat.

Jollife dan David P. Farington (2006) mengkategorisasikan empati menjadi dua yaitu empati kognitif dan empati afektif. Empati kognitif adalah pemahaman pada emosi orang lain. empati afektif didefinisikan keselarasan afektif pada keadaan emosi orang lain. Cohen dan Stayer Cohen and Strayer (1996) Empati didefinisikan "as the understanding and sharing in another 'semotional state or context" dengan arti "pemahaman dan penempatan posisi dalam keadaan emosi seseorang atau konteks".

\section{Etnis Batak}

Batak merupakan salah satu suku bangsa di Indonesia. Etnis batak merupakan salah satu etnis besar di Indonesia yang persebarannya hampir memenuhi semua wilayah yang ada di Indonesia. Orang batak sebagian besar mendiami daerah pegunungan Sumatra Utara, mulai dari perbatasan Daerah Istimewa Aceh di utara sampai ke perbatasan Riau dan Sumatra Barat di sebelah selatan. Selain itu, orang Batak juga mendiami tanah datar yang berada di antara daerah pegunungan dengan pantai timur Sumatra Utara dan pantai barat Sumatra Utara. Berdasarkan keterangan diawal maka orang Batak yang berada di Sumatra persebarannya meliputi: Dataran Tinggi Karo, Langkat Hulu, Deli Hulu, Serdang Hulu, Simalungun, Dairi, Toba, Humbang, Silindung, Angkola, dan Mandailing dan Kabupaten Tapanuli Tengah.

Etnis Batak sebagai salah satu golongan etnis di Sumatera sejak dahulu sampai kini selalu menempuh kebudayaannya menurut kepribadian sendiri. Tampaknya modernisasi yang terjadi dalam segala 
segi hidup zaman ini tidak mengubah kepribadian itu, karena orang-orang Batak berpedoman pada filsafat leluhur yang tertuang di atas landasan Dalihan $\mathrm{Na}$ Tolu. Begitu teguhnya prinsip yang mengikat sehingga mereka, baik secara golongan tetap mendasarkan hidupnya pada falsafah itu sejak dahulu sampai sekarang. Menurut dalihan na tolu, kedudukan seseorang terutama ditentukan oleh kedudukannya berdsarkan sistem kekerabatan yang dianut seluruh warga masyarakat. Azas ini tentu saja pada suatu saat akan menyebabkan seseorang yang mempunyai kedudukan resmi yang cukup tinggi harus "mengalah" kepada orang lain hanya karena orang lain itu kedudukan adatnya lebih tinggi dari pejabat resmi itu.

Terdapat sejumlah nilai yang berkaitan satu sama lain, sehingga membentuk sistem. Sistem tersebut, menjadi pedoman dan pendorong dalam menata kehidupan warga masyarakat.Sebagaimana dinyatakan oleh Basyral Hamidy Harahap dan Hotman M. Siahaan, nilai budaya Batak mencakup segala aspek kehidupan orang Batak. Dalam konteks ini, setidaknya ada sembilan nilai budaya utama orang Batak, yaitu kekerabatan, religi, hagabeon, hasangapon, hamoraon, hamajuon, hukum pahit dohot ukum, pengayoman, dan konflik.

Penelitian yang dilakukan oleh Darrick Jolliffe dan David P Farrington (2006) yang meneliti mengenai empati dasar dengan mengembangkan instrumen baru "BES" (Basic Empathy Scale). Penelitian ini dilatarbelakngi oleh alat instrumen "HES" (Hogan Empathy Scale), "QMEE" (Questionnaire Measure of Emotional Empathy), "IRI" (Interpersonal Reaktivitas Index) dianggap tidak mengukur empati kognitif dan empati afektif sepenuhnya. Item BES ini terdiri dari 40 item pada awalnya yang diberikan kepada 363 remaja di tahun 10 (kelas 1 SMA) atau usia sekitar 15 tahun di tiga sekolah di Hartfordshire, Inggris, yang 1 tahun kemudian item BES tersebut dikurangi menjadi 20 item dan diuji ulang kepada 357 remaja berbeda di usia dan sekolah yang sama dengan sebelumnya. Skala yang digunakan dalam instrumen tersebut adalah model skala Likert dengan rentang 1 hingga 5 .

Hasil dari Penelitian tersebut didapatkan bahwa wanita dinilai lebih tinggi daripada laki-laki dalam empati afektif dan empati kognitif. Empati berkore- lasi positif dengan kecerdasan untuk wanita, extraversion empati kognitif, neurotisisme empati afektif, keramahan, kesadaran untuk laki-laki, dan keterbukaan. Empati berhubungan positif dengan pengawasan orang tua dan status sosial ekonomi. Remaja yang akan membantu korban bullying memiliki empati yang tinggi.

\section{Metode Penelitian}

Jenis penelitian ini adalah penelitian kuantitatif. Metode yang digunakan dalam penelitian ini adalah metode penelitian deskriptif dengan teknik survei. Subjek penelitian yang terlibat dalam penelitian ini ada 18 mahasiswa bimbingan dan konseling Etnis Batak dari lima perguruan tinggi di Jakarta.

Tabel 1.1

Populasi Penelitian

\begin{tabular}{|c|c|}
\hline Universitas & Populasi \\
\hline Universitas Negeri Jakarta (UNJ) & 6 \\
\hline Universitas Muhammadiyah Hamka (UHAMKA) & 1 \\
\hline Universitas Asyafi'iyah & 1 \\
\hline Universitas Kristen Indonesia (UKI) & 5 \\
\hline Universitas Atmadjaya & 5 \\
\hline Jumlah Total & 18 \\
\hline
\end{tabular}

Sampel yang digunakan dalam penelitian ini didapat dengan teknik pengambilan sampel jenuh. Peneliti menggunakan teknik sampling gjenuhini karena jumlah populasi dibawah 30 orang.sampling jenuh ialah teknik pengambilan sampel apabila semua populasi digunakan sebagai sampel dan dikenal juga dengan istilah sensus. Sampel jenuh dilakukan bila populasi kurang dari 30 orang.Adapun alat pengumpul data atau instrumen yang digunakan dalam penelitian ini adalah instrumen baku " $\mathrm{Ba}$ sic Empathy Scale" yang telah diadaptasi dan disadur ke bahasa Indonesia.

\section{Hasil Penelitian dan Pembahasan}

Penelitian ini dilakukan melalui pemberian kuesioner pada mahasiswa BK etnis Batak di lima Universitas di DKI Jakarta yaitu Universitas Negeri Jakarta (UNJ), Univeristas Muhammadiyah Prof.Hamka (UHAMKA), Universitas Asyafi'iyah, Universitas Kristen Indonesia (UKI), Universitas Atmadjaya. Secara teoritik diharapkan data yang diperoleh melalui kuesioner dengan 20 item pernyataan yang 
diberikan kepada mahasiswa Bimbingan dan Konseling Etnis Batak diperoleh skor maksimal 100 dan skor minimal 20. Namun dalam kenyataannya secara empirik diperoleh skor maksimal 93 dan skor minimal 63 dengan rentang 67-80 dengan rata-rata 73 .

Tabel 1.2 Data Mahasiswa BK Etnis Batak

\begin{tabular}{|c|c|c|c|}
\hline Nilai Kategorisasi & Katagorisasi & Jumlah Orang & Persentase \\
\hline Tinggi & $\geq 81$ & 2 & $11 \%$ \\
\hline Sedang & $67-80$ & 14 & $78 \%$ \\
\hline Rendah & $\leq 67$ & 2 & $11 \%$ \\
\hline \multicolumn{2}{|c|}{ Jumlah } & 18 & $100 \%$ \\
\hline
\end{tabular}

Merujuk pada hasil yang telah disajikan pada bagian deskripsi data, secara keseluruhan tingkat empati dasar mahasiswa Bimbingan dan Konseling etnis Batak di DKI Jakarta berada pada posisi mayoritas sedang. Peneliti menggunakan seluruh sampel yang ada karena terbatasnya populasi mahasiswa bimbingan dan konseling etnis Batak di DKI Jakarta. Total 18 mahasiswa bimbingan dan konseling dari etnis Batak melakukan proses pengisian kuesioner yang tersebar di lima universitas sekitar wilayah DKI Jakarta.yaitu Universitas Negeri Jakarta (UNJ), Universitas Muhammadiyah Prof. Hamka (Uhamka), Universitas Asy-Syafi'iyah, Universitas Kristen Indonesia (UKI), Universitas Katolik Atmadjaya. Berdasarkan total sampel yang diambil, sebagian besar yaitu 14 mahasiswa (78\%) berada pada posisi sedang tingkat empati dasarnya. Sementara itu terdapat 2 mahasiswa (11\%) yang menempati posisi tinggi dan rendah pada tingkat empati dasarnya.

Empati dasar yang dimaksud dalam penelitian ini mengacu pada teori yang dimiliki oleh Jollife dan Farington yang merupakan adopsi teori dari Cohen dan Strayer, bahwa karakteristik empati dasar terbagi menjadi dua yaitu empati dasar aspek kognitif dan aspek afektif. Pertama, empati dasar aspek kognitif dapat terlihat dari proses memahami perasaan keadaan emosi atau konteks seseorang. Artinya, kita berada pada kondisi sebatas merasakan apa yang dialami oleh orang lain. Kedua,empati dasar pada aspek afektif yang ditandai dengan menempatkan posisi diri pada keadaan emosi atau konteks seseorang.

Berdasarkan hasil penelitian didapat hasil yang tidak jauh berbeda antara empati dasar aspek kognitif dan empati dasar aspek afektif pada keseluruhan populasi mahasiswa bimbingan dan konseling Etnis Batak. Hasil empati dasar pada aspek kognitif empati dasar mahasiswa bimbingan dan konseling Etnis Batak berada pada kategori empati dasar aspek kognitif tinggi terdapat 3 orang (17\%), empati dasar aspek kognitif pada kategori sedang terdapat 13 orang $(72 \%)$, dan sejumlah 2 orang $(11 \%)$ menempati posisi rendah. Demikian pula hasil penelitian pada empati dasar mahasiswa bimbingan dan konseling Etnis Batak pada kategori empati dasar aspek afektif tinggi terdapat 3 orang (17\%), empati dasar aspek afektif pada kategori sedang terdapat 12 orang (66\%), dan empati dasar aspek afektif pada kategori rendah terdapat 3 orang $(17 \%)$.

Selanjutnya hasil empati dasar berdasarkan jenis kelamin diperoleh data yang tidak jauh berbeda klasifikasinya. Pada mahasiswa laki-laki didapat data yang menarik, seluruh mahasiswa laki-laki Etnis Batak berada pada kategori sedang dengan jumlah 4 orang (100\%). Sedangkan hasil penelitian pada empati dasar aspek kognitif dan empati dasar aspek afektif menunjukkan hasil yang berbeda. Berikut data hasil empati dasar mahasiswa laki-laki pada empati dasar aspek kognitif dan empati dasar aspek afektif pada kategori tinggi terdapat 1 orang (25 $\%$ ), empati dasar aspek kognitif dan empati dasar aspek afektif kategori sedang terdapat 2 orang (50\%), serta empati dasar aspek kognitif dan empati dasar aspek afektif kategori rendah terdapat 1 orang (25 $\%)$.

Hasil penelitian pada mahasiswa perempuan menunjukkan data dari 14 orang mahasiswa perempuan terdapat 2 orang (14\%) yang memiliki empati dasar tinggi, sementara empati dasar pada kategori sedang terdapat 10 orang $(72 \%)$, dan empati dasar pada kategori rendah terdapat 2 orang (14\%). Lalu, pada empati dasar aspek kognitif mahasiswa perempuan pada kategori tinggi terdapat 2 orang (14\%), mahasiswa perempuan yang memiliki empati dasar aspek kognitif pada kategori sedang terdapat 9 orang (65\%), dan mahasiswa perempuan yang memiliki empati dasar aspek kognitif kategori rendah terdapat 3 orang (21\%). Selanjutnya pada empati dasar aspek afektif mahasiswa perempuan pada kategori tinggi terdapat 3 orang (21\%), empa- 
ti dasar aspek afektif mahasiswa perempuan pada kategori sedang terdapat 8 orang (58\%), dan empati dasar aspek afektif mahasiswa pada kategori rendah terdapat 3 orang $(21 \%)$.

Berdasarkan pada hasil yang diperoleh dari penelitian ini, diketahui bahwa mayoritas empati dasar mahasiswa BK Etnis Batak di lima Universitas berada pada klasifikasi sedang. Hal ini memberikan sebuah gambaran awal yang cukup baik, sebagai bekal bagi para calon konselor menghadapi situasi nyata di sekolah. Menarik menganalisa hasil penelitian mengenai empati dasar mahasiswa bimbingan dan konseling dari etnis Batak di DKI Jakarta. Tidak ada perbedaan yang signifikan antara mahasiswa laki-laki dan perempuan pada empati dasar keseluruhan maupun empati dasar aspek kognitif dan empati dasar aspek afektif. Semua mahasiswa bimbingan dan konseling Etnis Batak berada pada kategori sedang yang dapat diharapkan meningkat ke kategori tinggi.

Berdasarkan hasil gambaran empati dasar mahasiswa BK Etnis Batak diatas, peneliti berpendapat bahwa ada beberapa faktor yang mempengaruhi hasil tersebut. Diantaranya adalah faktor latar belakang kedua orang tua yang berasal dari Etnis Batak karena sudah lama menetap di Jakarta, tempat kelahiran responden di Jakarta, serta faktor lingkungan tempat tinggal responden yang terdiri daari beberapa Etnis lain seperti Jawa, Sunda, Minang, dan Betawi.

Berikutnya apabila kita menilik kepada beberapa nilai masyarakat Batak maka akan ditemukan bahwa empati dasar mahasiswa Etnis Batak sangat dipengaruhi oleh nilai-nilai tersebut. Salah satu yang menjadi dasar adalah dalihan na tolu atau kekerabatan yang begitu kuat dan mengakar dimanapun mereka berada. Misalnya, dalam satu kondisi ada diantara marga dari Etnis Batak mengalami suasana berkabung, pesta pernikahan, maka secara inisiatif para masyarakat Etnis Batak dari marga tersebut akan menghadiri acara tersebut. Meskipun nilai-nilai masyarakat Batak sangat kental mempengaruhi, akan tetapi karena beberapa faktor yang telah disebutkan diawal maka empati dasar mahasiswa bimbingan dan konseling Etnis Batak berada pada kategori sedang.

\section{Kesimpulan dan Saran}

Berdasarkan hasil analisis sebelumnya, berikut beberapa keimpulan yang dapat diambil pertama menurut hasil penelitian empati dasar secara umum, diperoleh data berdasarkan total skor empati dasar di lima universitas bahwa responden yang berada pada kategori tinggi sebanyak 2 orang, pada kategori sedang berjumlah 14 orang, dan sejumlah 2 orang berada pada kategori rendah, sehingga jumlah keseluruhan sebanyak 18 orang.Kedua, pada empati dasar aspek kognitif atau memahami perasaan keadaan emosi atau konteks seseorang, mahasiswa bimbingan dan konseling berada pada kategori sedang dengan 13 orang mahasiswa (73\%). Ketiga, pada empati dasar aspek afektif atau menempatkan posisi diri pada keadaan emosi atau konteks seseorang, mahasiswa bimbingan dan konseling berada pada kategori sedang dengan 12 orang mahasiswa (66\%).Berdasarkan hasil penelitian yang dilakukan, terdapat beberapa hal yang dapat dipelajari dan dikaji bersama tentang gambaran empati dasar mahasiswa BK etnis Batak di DKI Jakarta. Hasil penelitian ini menunjukkan bahwa tingkat empati dasar mahasiswa BK etnis Batak di DKI Jakarta berada pada tingkatan sedang. Sebagaimana tercermin pada hasil penelitian tingkat empati dasar mahasiswa Bk etnis Batak dengan kategori $11 \%$ (rendah), $78 \%$ (sedang), dan $11 \%$ (tinggi).

Berikutnya beberapa saran untuk para pihak terkait. Pertama untuk Jurusan Bimbingan dan Konseling perlu kiranya menyusun kurikulum yang tidak hanya mengembangkan kompetensi konselor dari sisi kognitif saja tetapi juga mengembangkan kompetensi yang mampu meningkatkan empati dasar para mahasiswa BK. Kedua, dosen perlu diberikan motivasi agar saat melakukan proses belajar mengajar didalam kelas proses peningkatan empati dasar dapat terwujud. Seperti dengan memberikan contoh kasus yang melatih mahasiswa untuk meningkatkan empati dasarnya. Ketiga, mahasiswa harus berperan aktif meningkatkan kemampuannya dalam mengelola empati dasar dengan berlatih melakukan peer guidance or peer counseling agar meningkatkan empati dasar antar mahasiswa. 


\section{Daftar Pustaka}

Cohen \& Strayer. (1996). Empathy in Conduct-Disordered and Comparation. Development Psikologi.

http://www.KBBI.co.id (diakses pada jam 15.00 hari Kamis tanggal 25 April 2014)

Koentjaraningrat. (2004). Manusia dan Kebudayaan Di Indonesia. Jakarta : Djambatan

Darrick Jolliffe\& David P Farrington, Basic Empathy Scale, (England - Cambridge University, Institute of Criminology, 2006)

Sunardi, PLB FIP UPI "Isu-isu Konseptual dan Metodologis dalam Hubungan dengan Penelitian Multikultural

Harahap, B.M \& Siahaan.1987 Orientasi Nilai-Nilai Budaya Batak. Jakarta : Sanggar Wilem Iskandar

Mulyana dan Jalaludin Rakhmat, Komunikasi Antarbudaya ( Bandung : PT Remaja Rosdakarya, 2005)

Fathur Rahman, Kualitas Empati dan Intensi Proposial Sebagai Dasar Kepribadian Konselor (Yogyakarta -
UNY: Jurnal Pendidikan dan Kebudayaan 2006)

Egan, "The Skilled Helper : A Problem Management and Opportunity-Development Approach to Helping 7th dikutip oleh Pedersen dkk, Inclusive Cultural Empathy : Making Relationships Central in Counseling and Psycotherapy, (United State : American Pschycologist Association, 2008)

Eisenberg,N.2002.Empathy and its Development. New York:Cambridge University Press

Goleman, Daniel 2007, Social Intelligence: Ilmu Baru tentang Hubungan Antar Manusia, PT Gramedia Pustaka Utama

http://www.Kemendikbud.go.id (diakses pada jam 12.00 hari Sabtu tanggal 26 April 2014)

Margono. 2004. Metode Penelitian Pendidikan, Jakarta: PT. Rhineka Cipta

Sugiyono, Metode Penelitian Pendidikan :Pendekatan Kuantitatif, Kualitatif, dan R\&D, (Bandung: Alfabeta, 2008) 